УДК 811.161.1'42

ББК 881.161.1'42:821.09

DOI: https://doi.org/10.17308/lic.2020.4/3088

\title{
АТТРАКТИВНЫЕ СВЯЗИ МАРКЕМ В РОМАНЕ В. В. НАБОКОВА «МАШЕНЬКА» И ИХ ВИЗУАЛИЗАЦИЯ
}

\author{
Ж. В. Грачёва
}

Воронежский государственный университет

\section{ATTRACTIVE CONNECTIONS OF MARKEMES IN V. V. NABOKOV'S NOVEL “MASHENKA" AND THEIR VISUALISATION}

\author{
Zh. V. Gracheva \\ Voronezh State University
}

\begin{abstract}
Аннотация: в статье рассматривается один из современных методов выявления ключевых слов текста - квантитативный маркемный анализ, произведенный на материале романа В. В. Набокова «Машенька» с помощью полученных в результате применения компьютерной программы (ПроТемАЛ) количественных данных, а также лемматизачии слов в автоматическом режиме с помощью программы ADD-2. Ha основе ИнТема и дистрибутивного анализа выделяются 50 маркем романа В. В. Набокова «Машенька», при этом учитываются контекстуальные значения и ассоциативные коннотации слов. Для проведения маркемно-семантического анализа с помощью программы «Cоnst_2018_v3» выявляется аттрактивность маркем (их способность «притягивать» друг друга в тексте), создается таблица аттрактивных пар, на основе которой строится граф, визуализирующий аттрактивные связи маркем в романе «Машенька» с помощью сортировки маркем в порядке убывания значений КоКона. На основе графа делается вывод о существовании в романе двух смысловых цеентров: "Прохлада», который ассоциативно отсылает $к$ ошущению «прохладной дымки» происходящего, и «Снег», соотносящегося со временем «снежного» петербургского периода любви и с Россией.

Ключевые слова: иифровая гуманитаристика, маркемология, индекс текстуальной маркированности, коэффициент констелляиии, интегральный маркемный вес, аттрактивные связи маркем, роман В. В. Набокова «Машенька».
\end{abstract}

\begin{abstract}
: the paper deals with one of the modern methods of identifying key words in the text-quantitative markeme analysis performed on the material of the novel by V. V. Nabokov: "Mashenka» with the help of quantitative data obtained as a result of using computer program (ProTemAl) and lemmatization of words in automatic mode with the help of ADD-2 program. Based on InTem and distribution analysis, 50 markemes of the novel by V. Nabokov were distinguished. The analysis takes into account contextual meanings and associative connotations of the words. To carry out the markeme-semantic analysis, the program «Const_2018_v3» detects the "attractiveness" of markemes (their ability to "attract» each other in the text), creates a table of attractive pairs, based on which a graph is built, visualizing the attraction connections of markemes in the novel «Mashenka» by sorting markemes in descending order of CoCon values. Based on the graph the conclusion is made about the existence of two semantic centers in the novel: "Coolness», which associatively refers to the feeling of "Cool haze» of what is happening, and «Snow», which correlates with the time of «Snow» the St. Petersburg's period of love and with Russia.

Key words: digital humanities, markemology, index of textual markedness, coefficient of constellation, integrated markeme weight, attractive connections by markeme, $V$. V. Nabokov's novel «Mashenka».
\end{abstract}

\section{Введение}

Проблемой извлечения слов, на остриях которых «растянут», по словам А. Блока, весь текст, озадачи- вались многие исследователи. Вашему вниманию предлагается один из современных методов выявления таких слов - квантитативный метод маркемного

(C) Грачёва Ж. В., 2020

Контент доступен под лицензией Creative Commons Attribution 4.0 License.

The content is available under Creative Commons Attribution 4.0 License. 
анализа, позволяющий с помощью «жара холодных числ» увидеть «дар божественных видений».

\section{Материалы и методы исследования}

Представленное исследование посвящено маркемному и лексико-семантическому анализу романа В. В. Набокова «Машенька».

Маркемный анализ разработан в рамках квантитативной лингвистики А. А. Кретовым [1-4] и А. А. Фаустовым [4-6] и связан с изучением крупных текстовых массивов. Для получения количественных данных была применена компьютерная программа (ПроТемАЛ), созданная под руководством А. А. Кретова и И. Е. Ворониной разработчиком И. В. Поповой [7]. Лемматизация слов осуществляется в автоматическом режиме с помощью программы ADD-2 (автор - M. В. Катов), использующей лемматизатор MyStem, находящийся в свободном доступе.

В основе маркемологии лежит метод маркемного анализа - выделения так называемых маркем из всей совокупности употребляемых автором словоформ. Маркема выделяется на основе «индекса текстуальной маркированности» (далее ИнТеМ), который зависит от двух величин: ее длины в звуках и частоты встречаемости лексемы в текстовом массиве писателя.

Величина ИнТеМа связана с зависимостью между длиной словоформы и частотой ее употребления, которая была описана Дж. К. Ципфом [8-9] и вычисляется по формуле: ИнТеМ = Ч-вес - Д-вес, где Ч-вес - субъективная составляющая (вес словоформы, зависящий от ее частоты); Д-вес - объективная составляющая (вес словоформы, зависящий от ее длины в звуках).

Формула вычисления весов, которая была сформулирована В. Т. Титовым [10], позволяет привести к одному виду вес словоформ в тексте по частоте и по длине и разместить их в интервале от 1 до 0.

$$
P r_{i}=\frac{\sum r-R_{1-i}}{\sum r},
$$

где $\Sigma r$ - сумма единиц всех рангов, $R_{1-i}$ - сумма единиц от первого до данного ранга частоты.

Определение ИнТеМа каждой из лексем осуществляется программой ПроТемАЛ, составляющей словарь всех словоформ, используемых в романе В. Набокова «Машенька», с указанием их частоты и длины, Ч-веса и Д-веса и ИнТеМа каждой из словоформ.

Кроме того, для отбора маркем-имен А. А. Кретовым введены семь фильтров - грамматических, семантических, стилистических. Среди них, например, такие как использование в единственном числе, в именительном падеже, неодушевленность; не учитываются имена собственные, стилистически окрашенная лексика, обращения и вводные слова, назва- ния месяцев и дней недели, часто употребляемые «антуражные» слова, лексика, обозначающая несимволические понятия, и др. Каждый из этих фильтров может быть в той или иной степени видоизменен в зависимости от особенностей анализируемого материала: в каком-то случае дни недели могут стать маркемами, в каком-то - имена собственные (как, например, при анализе романа «Машенька» в качестве маркемы было выделено слово Россия), в каком-то случае маркемой становится слово во множественном числе, если семантика лексем во множественном числе и единственном различаются) и т. д.

Вопрос о том, является ли то или иное слово маркемой, в представленном исследовании решался на основе ИнТеМа и дистрибутивного анализа (учитывались прежде всего контекстуальные значения слов и выявлялась их ассоциативная «нагруженность»). Так были выделены все 50 маркем романа «Машенька».

Для проведения маркемно-семантического анализа был произведен еще один тип расчета - выявление аттрактивности маркем, т. е. их способности притягивать друг друга в тексте. А. А. Фаустовым и А. А. Кретовым было установлено, что произведения, в которых наблюдается максимальное скопление маркем, как правило, являются типичными, характерными для данного автора, содержа специфику его художественного мира в максимально концентрированном виде. А. А. Фаустов также установил, что не все маркемы в равной мере обладают аттрактивностью. Характеризующая совместную встречаемость (аттрактивность) каждой пары маркем величина была названа коэффицчиент констелляциии (сокращенно КоКон) [11].

Получение значений КоКона осуществлялось с помощью программы «Const_2018_v3» (автор М. В. Катов).

Сортировка аттрактивных пар в порядке убывания значений КоКона позволила построить граф, на основе которого осуществляется визуализация аттрактивных связей маркем в романе «Машенька» в соответствии с изложенными ниже правилам.

\section{Правила построения графа визуализации аттрактивных связей маркем в романе «Машенька» ${ }^{1}$}

Построение начинается с пары с максимальным КоКоном, помечаемой особым образом.

За исходную принимается маркемная доминанта (маркема с максимальным ИнТеМом).

Места при маркеме заполняются по часовой стрелке, начиная с правой позиции (согласно приня-

${ }^{1}$ Общие подходы к построению графа разработаны в ходе консультаций с А. А. Кретовым. 
тому правилу письма и чтения: слева - направо, сверху - вниз). Если количество мест при маркеме не превышает 4, то они располагаются на графе последовательно: справа, снизу, слева, сверху; если количество больше 4, то окружность делится на 8 частей.

При построении графа исходной считается маркема, встречавшаяся ранее (уже представленная на графе).

Порядок использования пар определяется убыванием значения КоКона (от большего к меньшему).

В случае равенства значений КоКона пары ранжируются по убыванию суммарного КоКона представленных в них маркем.

В случае равенства суммарного КоКона представленных в них маркем - в порядке убывания ИнТема представленных в парах маркем.

Для обеспечения прозрачности и наглядности при построении графа используются исключительно связи с максимальным значением КоКона.

Узлами графа являются маркемы с максимальным (на данный момент) значением КоКона, ребрами значения КоКона.

Приступим к построению графа аттрактивных корреляций маркем, используя материал таблицы, в которой приведены 663 пары маркем с положительным ИнТемом. Поскольку объем статьи не позволяет представить всю таблицу аттрактивных пар, а без нее затруднено понимание алгоритма построения графа, приведем в качестве примера первые 30 пар (таблица). Остальные будут обрабатываться по аналогии с представленными.

Т а б л и ц а

Список попарных корреляциий (Пары + )

\begin{tabular}{|c|c|c|c|}
\hline № & А & В & С \\
\hline 1 & прохлада & *предчувствие & 0,969 \\
\hline 2 & мир & прохлада & 0,951 \\
\hline 3 & облако & прохлада & 0,951 \\
\hline 4 & мир & голос & 0,944 \\
\hline 5 & образ & прохлада & 0,934 \\
\hline 6 & образ & голос & 0,928 \\
\hline 7 & мир & *предчувствие & 0,927 \\
\hline 8 & облако & *предчувствие & 0,925 \\
\hline 9 & мир & образ & 0,922 \\
\hline 10 & цветок & женственность & 0,92 \\
\hline 11 & образ & *предчувствие & 0,918 \\
\hline 12 & голос & прохлада & 0,917 \\
\hline 13 & прохлада & воспоминание & 0,915 \\
\hline 14 & образ & воспоминание & 0,909 \\
\hline 15 & мир & воспоминание & 0,905 \\
\hline
\end{tabular}

\begin{tabular}{|c|c|c|c|}
\hline 16 & поток & счастие & 0,904 \\
\hline 17 & чудо & женственность & 0,904 \\
\hline 18 & облако & воспоминание & 0,903 \\
\hline 19 & голос & воспоминание & 0,9 \\
\hline 20 & снег & судьба & 0,899 \\
\hline 21 & облако & образ & 0,894 \\
\hline 22 & мир & ночь & 0,893 \\
\hline 23 & облако & мир & 0,889 \\
\hline 24 & жизнь & человек & 0,884 \\
\hline 25 & голос & *предчувствие & 0,88 \\
\hline 26 & мир & небо & 0,875 \\
\hline 27 & небо & образ & 0,873 \\
\hline 28 & облако & голос & 0,871 \\
\hline 29 & предчувствие & воспоминание & 0,87 \\
\hline 30 & любовь & письмо & 0,865 \\
\hline
\end{tabular}

Прокомментируем процесс построения графа.

1. Извлекаем пары маркем с положительным значением КоКона и переносим на лист «Пары+», с которым дальше работаем.

2. Число пар, отсортированных в порядке убывания значений КоКона (т. е. в порядке убывания их взаимной аттрактивности = совместной встречаемости), - 663. Значение КоКона не имеет направления (вектора). Оно характеризует совместную встречаемость двух маркем в тексте. Стрелкой-вектором будет обозначено направление поступательного «раскручивания полотна» графа.

3. Условно примем за исходную точку маркему «предчувствие», поскольку она обладает (как указывалось выше) как минимум двумя основными параметрами: самым высоким ИнТемом $(0,41174)$ и входит в пару с максимальным значением КоКона $(0,969)$. Помечаем ее знаком «*»: «*предчувствие».

4. Чтобы далее отсеять уже задействованные (т. е. исходные) маркемы в парах, заменяем во всех строках таблицы «прохлада» на «_прохлада» и «* предчувствие» - на «"*предчувствие».

5. В столбцце А - «левые» маркемы, в столбце В - «правые» маркемы. («левые» - в левом столбце, «правые» - в правом столбце). Название условное и произвольное. В столбце С - значения КоКона.

6. Далее совершаем ряд операций, направленных на автоматическое устранение тех строк, которые будут уже обработаны (отмеченные предшествующими обоим словам подчеркиваниями в паре на одной строке). Описание операций опускаем.

7. Возвращаемся к построению графа. Рисуем «предчувствие» и справа от него - «прохлада». Поскольку приоритет у правых и нижних позиций, естественно предположить, что граф будет расти преимущественно вправо и вниз. Поэтому первую 
пару помещаем в левый верхний угол, оставив место для двух маркем слева и двух маркем сверху. На ребре помещаем значение КоКона пары «предчувствие прохлада» - 0, 969.

8. Следующая (по убыванию КоКона) строка «мир -_прохлада». Справа к «_прохладе» присоединяем «мир» и на ребре отмечаем КоКон - 0,951.

9. По всему файлу заменяем «мир» на «_мир».

10. Удаляем строку (2) «_мир - прохлада», а вместе с ней и другие ранее задействованные.

11. Следующая строка (3) - «облако -_прохлада». Присоединяем «облако» вниз к маркеме «_прохлада». Пишем на ребре 0,951 .

12. Заменяем «облако» на « облако». Удаляем «_облако -_прохлада», а с ней и другие ранее задействованные.

13. Следующая строка (4) - «_мир - голос». Присоединяем к маркеме «_мир» справа «голос». Пишем на ребре 0,944 .

14. Заменяем «голос» на « голос», удаляем строку (4).

15. Работаем со строкой 5 - «образ - прохлада». «_Образ» присоединяем к маркеме «прохлада» сверху. На ребре пишем 0,934. Перед «образ» ставим подчеркивание. Удаляем строку 6.

16. Строки 7, 8, 9 удалены ранее.

17. Следующая «рабочая» строка - 10 «цветок женственность» провисает: ни одно из этих слов не было задействовано в графе.

18. Строки 11-12 удалены ранее.

19. Строка 13 «_прохлада - воспоминание». Присоединяем «воспоминание» к маркеме «_прохлада». Это 5-е ребро, связывающее слово «ппрохлада» с другими маркемами. Отмечаем, на ребре пишем 0,915.

20. Строки 14-15 удалены ранее.

21. Строка 16 «поток - счастье» и строка 17 «чудо - женственность» провисли.

22. Строки 18-19 удалены ранее.

23. Строка 20 «снег - судьба» зависает.

24. Строка 21 удалена ранее.

25. Далее не указываются строки, обе маркемы в которых задействованы в графе ранее и удалены.

26. Строка 22 «_мир - ночь» рабочая; на графе к маркеме «_мир» внизу присоединяем «ночь». На ребре пишем 0,893 .

27. Строка 24 «жизнь - человек» провисает.

28. Строка 26 «_мир - небо» рабочая; к слову «_мир» вверх присоединяем «небо»; на ребре пишем $8 \overline{7}$.

29. Строки 30 «любовь - письмо», 31 «чудо - цветок», 32 «весна - берег», 33 «снег - письмо» провисают.

30. Строка 34 «чудо - ночь» рабочая. К маркеме «_ночь» справа присоединяем «чудо»; на ребре пишем 0,859 .

31. Строка 17 «_чудо - женственность», ранее провисшая, стала рабочей. Присоединяем справа к маркеме «_чудо» маркему «женственность»; на ребре пишем $0, \overline{904}$.

32. С появлением слова женственность строка 10 «цветок -_женственность» стала рабочей; присоединяем к маркеме «_женственность» справа «цветок»; на ребре пишем 0,920.

33. Строка 32 «весна - берег», строка 33 «снег письмо», 36 «поток - снег», 39 «птица - снег» зависают.

34. Строка 40 «_облако - воздух» рабочая; справа к маркеме «_облако» присоединяем «воздух»; на ребре пишем 0,843 .

35. Строки 41 «снег - счастье», 43 «снег - любовь», 44 «птица - письмо» зависают.

36. Строка 45 «_облако - прошлое» рабочая; снизу к маркеме « облако» присоединяем «прошлое»; на ребре пишем 0,834 .

37. Строка 46 «поток - судьба» зависает.

38. Строка 48 «_образ - человек» рабочая; справа присоединяем к маркеме « образ» маркему «человек»; пишем на ребре 0,827 .

39. Строки 50 «любовь - поезд»; 51 «мысль письмо», 53 «письмо - счастие» зависают.

40. Строка 24 «жизнь - _человек» становится рабочей; справа к маркеме «_человек» присоединяем «жизнь»; на ребре - 0,884.

41. Строки 56 «слабость - солнце», 58 «мысль любовь», 59 «имя - темнота» зависают.

42. Строка 59 «зеркало -_человек» рабочая; снизу к маркеме «_человек» присоединяем «зеркало»; на ребре пишем 0,803 .

43. Строки 60 «поток - поезд», 63 «судьба - письмо», 65 «снег - поезд», 66 «судьба - счастие», 67 «блеск - счастие», 71 «закат - ветер», 72 «снег блеск», 73 «птица - любовь» зависают.

44. Строка 74 «темнота -_жизнь» рабочая; справа к маркеме «_жизнь» присоединяем маркему «темнота»; на ребре $-0,787$.

45. Строки 78 «снег - мысль», 85 «судьба - поезд» зависают.

46. Строка 58 «имя -_ темнота» становится рабочей; к маркеме «_темнота» присоединяем «имя»; на ребре пишем $0,8 \overline{0} 6$.

47. Строки 95 «поезд - счастие», 98 «весна - чувство», 99 «птица - судьба», 101 «птица - мысль», 102 «поток - блеск», 104 «поезд - мысль», 105 «мысль - счастие», 108 «судьба - любовь» зависают.

48. Строка 109 «_цветок - тень» рабочая; к маркеме «_цветок» присоединяем справа «тень»; на ребре $-0,73 \overline{7}$.

49. Следующая рабочая строка 110 «сердце предчувствие»; снизу к маркеме «_предчувствие» присоединяем «сердце»; на ребре $-\overline{0}, 733$.

50. Строки 111 «мысль - блеск», 113 «берег - счастие», 115 «берег - письмо», 119 «любовь - счастие», 125 «блеск - письмо», 127 «письмо - поезд», 128 «птица - счастие», 130 «птица - поток» зависают. 
51. Строка 132 «_воздух - солнце» рабочая; справа к маркеме «_воздух» присоединяем «солнце»; на ребре $-0,711$.

52. Возвращаемся к ранее зависшей строке 56 «слабость -_солнце»; справа к маркеме «_солнце» присоединяем маркему «слабость»; на ребре - 0,815;

53. С этого момента начинается постепенное возвращение в работу ранее пропущенных строк; однако процесс зависания новых строк не ослабеет, а будет нарастать.

54. Строки 134 «птица - поезд», 140 «поток письмо», 142 «блеск - поезд», 149 «поток - любовь», 153 «судьба - блеск» зависают.

55. Строка 158 «_имя - сумерки» рабочая; справа к маркеме «_имя» присоединяем «сумерки»; на ребре $-0,659$.

56. Следующая рабочая строка 160 «_облако прелесть»; к маркеме «_облако» слева присоединяем «прелесть»; на ребре - 0,656.

57. Строки 165 «любовь - блеск», 166 «поток мысль», 169 «птица - блеск», 170 «ветер - блеск», 177 «берег - судьба», 178 «берег - чувство», 179 «ветер - поезд», 183 «ветер - день», 188 «поток - берег», 192 «снег - ветер», 198 «поток - ветер», 200 «судьба - мысль», 203 «мысль - день», 208 «утро волос» зависают.

58. На этом процесс лавинообразного зависания строк останавливается, и начинается возвращение ранее пропущенных.

59. Строка 211 «_цветок - Россия» рабочая; к маркеме « цветок» снизу присоединяем «Россия»; на ребре $-0, \overline{5} 98$.

60. Следующая рабочая строка - 224 «закат -_ слабость»; к маркеме «_слабость» справа присоединяем «закат»; на ребре - $\overline{0}, 577$.

61. Возвращаемся, в связи с появлением маркемы «закат», к строке 71 «_закат - ветер»; справа к маркеме «_закат» присоединяем маркему «ветер»; на ребре - 0,789.

62. Следующая рабочая строка 170 «_ветер блеск» (из зависших ранее строк); к маркеме «_ветер» присоединяем справа маркему «блеск»; на ребре 0,644 .

63. Возвращаемся к строке 67 «_блеск-счастие»; к маркеме «_блеск» присоединяем справа маркему «счастие»; на ребре - 0,792.

64. Возвращаемся также к строке 16 «поток _счастие»; к маркеме «_счастие» справа присоединяем маркему «поток»; на ребре - 0,904.

65. Следующая рабочая строка - 36 «_поток снег»; к маркеме «_поток» справа присоединяем «снег»; на ребре $-0, \overline{8} 54$.

66. Следующая рабочая строка (в связи с появлением маркемы «снег») - 20 «_снег - судьба», справа к маркеме «_снег» присоединяем маркему «судьба»; на ребре $-\overline{0,899 .}$.

67. Следующая рабочая строка - 33 «_снег - письмо»; к маркеме «_снег» снизу присоединяем маркему «письмо»; на ребре - 0,865.
68. Следующая рабочая строка 32 «любовь _ письмо»; справа к маркеме «_письмо» присоединяем маркему «любовь»; на ребре - 0,865.

69. Следующая рабочая строка 39 «птица-_снег»; сверху к маркеме «_снег» присоединяем маркему «птица»; на ребре $-\overline{0}, 844$.

70. Следующая рабочая строка 50 «_любовь - поезд»; к маркеме «_любовь» справа присоединяем «поезд»; на ребре - 0,825 .

71. Работаем со строкой 51 «мысль - _письмо»; снизу к маркеме «_письмо» присоединяем «мысль»; на ребре $-0,825$.

72. В работу включается строка 113 «берег__счастие»; снизу к маркеме «_счастие» присоединяем «берег»; на ребре - 0,731.

73. Следующая рабочая строка 32 «весна - берег»; к маркеме «_берег» справа присоединяем маркему «весна»; на ребре - 0,862.

74. Возвращаемся к строке 98 «_весна - чувство»; справа к маркеме «_весна» присоединяем «чувство»; на ребре $-0,760$.

75. Рабочей становится строка 183 «_ветер день»; к маркеме «_ветер» снизу присоединяем «день»; на ребре - $0, \overline{6} 30$.

76. Следующая рабочая строка 230 «_ветер - запах»; к маркеме «_ветер» присоединяем сверху маркему «запах»; на ребре - 0,570.

77. Работаем со строкой 234 «утро - _запах»; присоединяем справа к маркеме «_запах» маркему «утро»; на ребре - 0,563.

78. Возвращаемся к строке 208 «_утро - волос»; справа от маркемы «_утро» рисуем «волос»; на ребре $-0,602$.

79. Следующая рабочая строка 250 «память _Россия»; справа от маркемы «_Россия» размещаем на графе маркему «память»; на ребре - 0, 541.

80. Работаем со строкой 262 «_день - отражение»; справа от маркемы «_день» рисуем маркему «отражение»; на ребре - 0, $\overline{5} 25$.

81. Новая рабочая строка 297 «_чувство - лицо»; справа к маркеме «_чувство» присоединяем «лицо»; на ребре $-0,461$.

82. Работаем со строкой 343 «символ -_темнота»; к слову «_темнота» снизу присоединяем маркему «символ»; на ребре - 0,389.

83. Обрабатываем строку 388 «звезда__Россия»; к маркеме «Россия» снизу присоединяем маркему «звезда»; на ребре - 0,337.

84. Все строки, в которых были отмечены маркемы с максимальным положительным КоКоном, обработаны. Граф построен.

\section{Результаты исследования}

Результатом предложенного выше метода визуализации аттрактивных связей в тексте романа «Машенька» стал граф, представленный на рис. 1. 


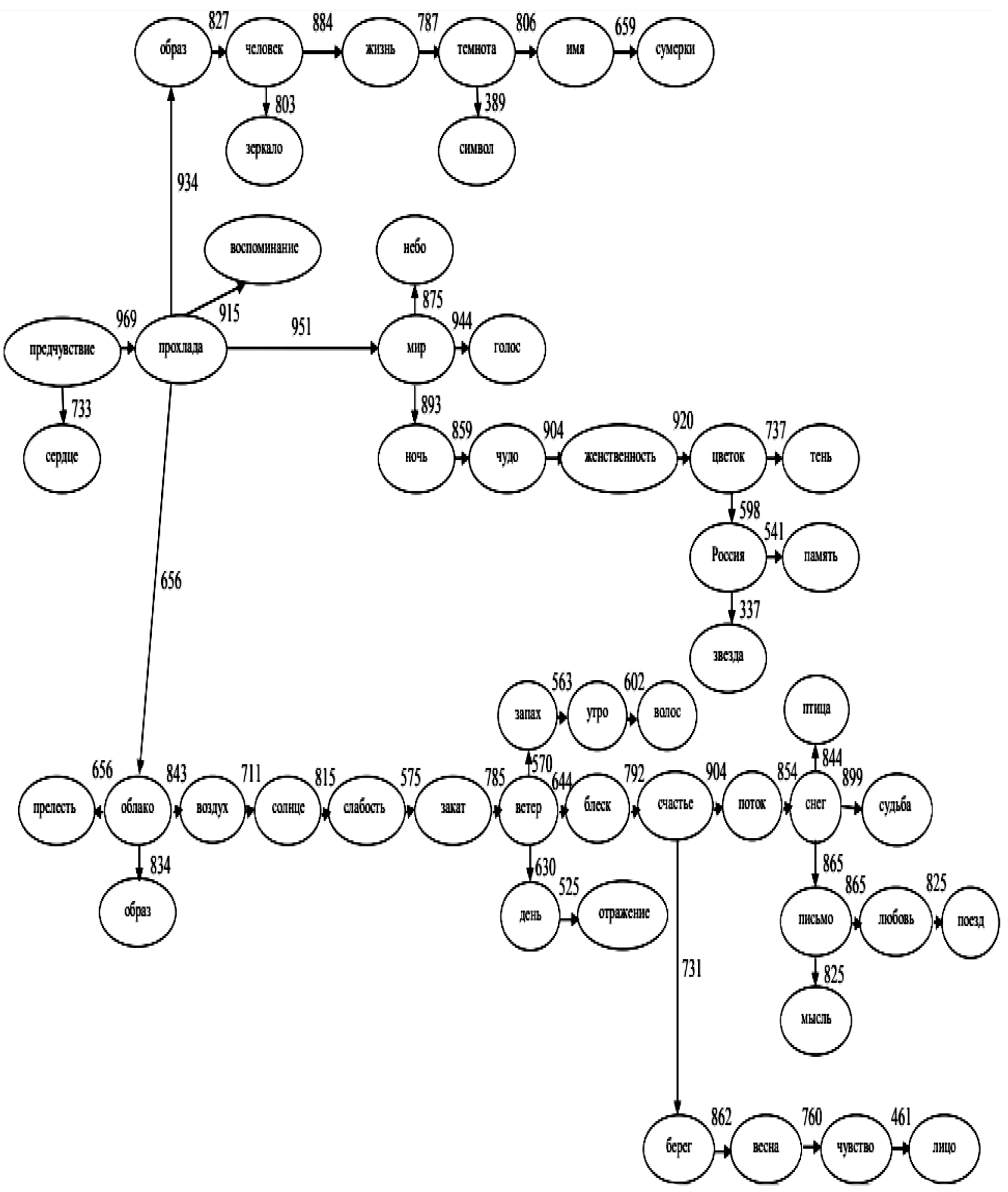

Puc. 1. Максимальные аттрактивные связи маркем в романе В. В. Набокова «Машенька»

Сделаем ряд общих замечаний по представленному выше рис. 1.

1. Отправной точкой стала маркема предчувствие, поскольку она обладает как минимум двумя основными параметрами: у этой маркемы самый высокий ИнТем $(0,41174)$ и она входит в пару с максимальным значением КоКона $(0,969)$.
2. В ходе исследования было выявлено, что (при средней корреляции 0,042) максимальная корреляция в романе «Машенька» $(0,969)$ возникает между словами прохлада и предчувствие, минимальная $(-0,974)$ - между словами прохлада и письмо.

3. Максимальным числом связей обладают в романе следующие маркемы: 
прохлада - 5 связей;

мир, облако, снег, ветер - 4 связи;

человек, темнота, ияветок, Россия, счастие, письмо - 3 связи.

4. Маркема прохлада-смыслообразующий центр первого, наиболее нагруженного подграфа, который условно назван «Прохлада» по слову, обладающему максимальной аттрактивностью.

5. Маркема снег - смыслообразующий центр второго подграфа, условно назовем его «Снег». Во втором подграфе есть еще один центр, который, как и снег, обладает четырьмя связями, - это маркема ветер. Она появляется практически на линии разграничения двух подграфов и образует периферийный центр притяжения тех маркем, которые имеют малый КоКон. Но постепенно от пониженного в ранге центра ветер раскручивается новый подграф из накопившихся провисших маркем с увеличивающимся КоКоном. Они встраиваются в множество с центром более высокого ранга «Снег», имеющим 4 связи и притягивающим маркемы с высоким КоКоном.

6. Граница между двумя подграфами проходит между маркемами слабость и закат (коэффициент аттракции этих маркем 0,577). Она обусловлена самой логикой аттрактивного поведения маркем: множество «Прохлада» постепенно накапливается, что проявляется через большое количество «провисающих» строк в процессе построения графа. В таблице граница между двумя множествами обусловлена концентрацией отрицательных значений КоКона: маркемы на определенном этапе словно «избегают» друг друга, отталкиваются, а потом начинают «встраиваться», занимая свое место на графе. Возникающие «нерабочие» строки образуют «сгущения» связей внутри каждого множества. На графе они не указаны, так как их обозначение не позволило бы увидеть обобщенную картину притяжения маркем. Однако это можно увидеть при описании процесса построения графа. Граница «слабость - закат», проходящая между двумя основными подграфами, обусловлена также тем, что именно от этой пары маркем с КоКоном 0,577 начинается увеличение КоКона в обе стороны: и вправо, и влево; и в направлении подграфа «Прохлада», и в направлении подграфа «Снег».

Остановимся на кратком анализе трех определяющих содержание романа маркем, выявленных в процессе визуализации аттрактивных связей: «предчувствие», «прохлада» и «снег».

Маркема предчувствие имеет доминантное расположение на ассоциативной смысловой прямой: в качестве отправной единицы маркемно-семантического анализа романа «Машенька», как указывалось выше, избираем доминантное слово с наибольшим ИнТеМом - предчувствие $(0,41175)$ : к нему притягиваются маркемы на основе семантической валентности.
Согласно исследованию Е. В. Урысон, предчувствие - «(неотчетливое) знание того, что произойдет $<\ldots>$ и что влияет на жизнь субъекта или кого-то из его близких, которое субъект имеет благодаря тому, что воспринял нечто, недоступное обычному человеческому восприятию, или особое чувство, какое бывает, когда субъект имеет такое знание» [12, с. 830]. Е. В. Урысон указывает на ряд смысловых признаков (сем) слова: 1) способность обозначать знание чего-то или состояние души субъекта, которое бывает при таком знании; 2) период времени, к которому относится то, что знает субъект, - это будущее; 3) открывающееся знание настолько важно, что должно изменить жизнь субъекта; 4) характер возникновения этого знания необъясним: оно появляется само по себе, помимо воли человека; 4) орган, где возникает предчувствие, - душа или сердце; 5) такое знание характеризует субъект: бывает у немногих людей, недоступно обычному человеческому восприятию $[12$, c. 830$]$.

Обратившись к контекстуальной реализации слова предчувствие в романе «Машенька», можно увидеть репрезентацию рядом с ним представленных через другие словоформы выделенных выше сем, а также словоформы, отсылающие прямо или косвенно к другим маркемам текста: «B этой комнате, где в иестнадияать лет выздоравливал Ганин, и зародилось то счастье, тот женский образ, который, спустя месяц, он встретил наяву. В этом сотворении участвовало все, - и мягкие литографии на стенах, и щебет за окном, и коричневый лик Христа в киоте, и даже фонтанчик умывальника. Зарождавшийся образ стягивал, вбирал всю солнечную прелесть этой комнаты и, конечно, без нее он никогда бы не вырос. В концее конциов это было просто юношеское предчувствие, сладкие туманы, но Ганину теперь казалось, что никогда такого рода предчувствие не оправдывалось так совершенно»² (выделено нами. - Ж. Г.) [13, с. 57-58]. В контексте эксплицируется еще одна, не указанная выше, окказиональная сема маркемы предчувствие: порождается измененным, пограничным (не «наяву»), связанным с физической или духовной болезнью состоянием сознания.

В приведенном предложении маркема предчувствие повторяется дважды, причем сначала в роли предиката, а затем - субъекта. В первом случае она характеризует зарождение ситуации будущего, которое изменит жизнь героя, во втором констатирует «совершенную» реализацию предчувствия. Как видим, соединяются два времени: будущее и прошлое, порождая особый набоковский хронотоп: прошлое как реализованное будущее (о предчувствии в контексте говорится в прошедшем времени). Такого рода

${ }^{2}$ В контекстах подчеркиванием выделяются словоформы, отсылающие к другим маркемам романа. 
парадоксальное осмысление времени, которое «предчувствуется» через маркему предчувствие, можно иллюстрировать рисунком самого В. В. Набокова, который визуализирует на нем свое понимание движения времени (рис. 2).

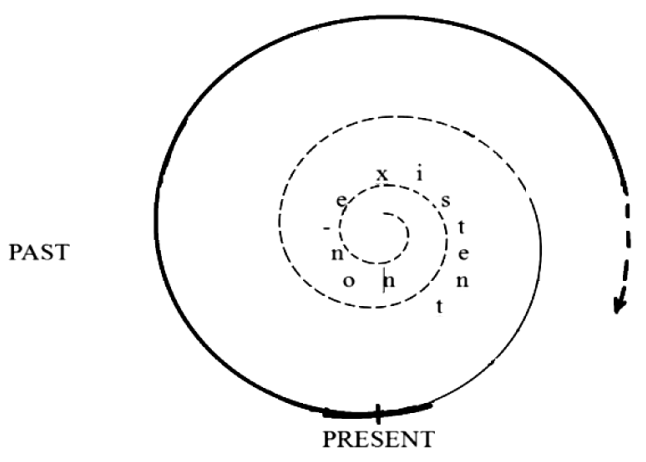

Puc. 2. Схема В. В. Набокова, изображающая движение времени

Эта схема В. Набокова приведена в книге М. Гришаковой «The models of space, time and vision in V. Nabokov's fiction». М. Гришакова, комментируя этот рисунок, пишет о том, что по Набокову, «увеличивающиеся наслоения прошлого закреплены в настоящем как мотивация для поступка, воображаемого будущего, вновь становящегося прошлым <..> будущее не существует $<\ldots>$ оно неизменно вписывается в прошлое через непосредственный момент настоящего. Время имеет спиральную форму, и только небольшая часть этой спирали видима и доступна человеку: недавнее прошлое и настоящее. Пунктирные линии обозначают «несуществующие» части времени: отдаленное прошлое и будущее» ${ }^{3}$ [14].

Маркема предчувствие имеет доминантное расположение на ассоциативной смысловой прямой: она встраивается в историческое пророческое пространство текста и появляется-проявляется, чтобы дать начало глубинному смысловому развитию романа.

Анализ синтагматики представленного выше контекста указывает на связь маркемы предчувствие со словоформами, прямо отсылающими к маркемам счастье $(0,10534)$ («то счастье»), женственность $(0,19733)$ и образ $(0,00465)$ («женский образ», «зарождающийся образ»), солнце $(0,04993)$ и прелесть (0,05991) («солнечную прелесть»), свет $(-0,00463)$, лицуо («лик Христа») и косвенно на связь с маркемой отражение («зародилось» - «оправдалось»). Также на синтагматическую аттракцию маркемы предчувствие с другими маркемами текста прямо указывают сочетания употребляемых в тексте глаголов: зародилось («счастье»), участвовало («в сотворении»), стягивал («образ»), вбирал («прелесть»); все они

${ }^{3}$ Объяснение представлено в книге М. Гришаковой по-английски. Перевод на русский наш. - Ж. Г. реализуют в представленном контексте сему «процесс зарождения нового».

В контексте эксплицируется еще одна, не указанная выше, окказиональная сема маркемы предчувствие: порождается измененным, пограничным (не «наяву»), связанным с физической или духовной болезнью состоянием сознания.

Взаимно притянутые слова предчувствие и прохлада образуют ту точку аттрактивного (а значит, и семантического напряжения), которая, в свою очередь, станет узловой. Именно маркема прохлада соединится сразу пятью связями с маркемами с высоким КоКоном и образует пять точек напряжения: «предчувствие - прохлада» $(0,969)$, «прохлада - мир» $(0,951)$, «прохлада - облако» $(0,951)$, «прохлада воспоминание» $(0,915)$. Лексема «прохлада» реализует в тексте романа:

1) прямое денотативное значение (состояние, описывающее температуру воздуха; приятное, комфортное для человека ощущение): Дни пошли радостные, бодрые. В усадьбе была прохлада, плаши солнияа на паркете. И через две недели он уже до одури катался на велосипеде, лупил по вечерам в городки с сыном скотниць [13, с. 58];

2) переносное денотативное значение (воздух, характеризующийся приятной низкой температурой): А потом, под мостом, хльнула темная прохлада, сверху был тяжельй стук копьт и колес, и когда опять лодка выпльла, солнче ослепило, сверкнуло на кониах весел, выхватило телегу с сеном, которая как раз проезжала по низкому мосту, и зеленый скат, и над ним белье колонны большой заколоченной усадьбы александровских времен [13, с. 75];

3) коннотативное переносное значение (ощущение, порожденное исходящими флюидами невинности, духовной строгости, чистоты; состояние, возникшее в результате созерцания человека, жизнь которого подходит к концу; отсылка к маркеме-концепту «женственность»): Девять лет тому назад... Лето, усадьба, тиф... Удивительно приятно выздоравливать после тифа. Лежишь, словно на волне воздуха; еще, правда, побаливает селезенка, и выписанная из Петербурга сиделка трет тебе язык по утрам - вязкой после сна - ватой, пропитанной портвейном. Сиделка очень низенького роста, с мягкой грудью, с проворными короткими руками, и идет от нее сыроватьй запах, стародевичья прохлада. Она любит прибаутки, японские словечки, оставшиеся у нее от войны четвертого года. Личо с кулачок, бабье, щзербатое, с острым носиком, и ни один волосок не торчит из-под косынки [13, с. 56].

Следует заметить, что анализируемый контекст оказывается насыщен маркемами, содержащими важные для понимания романа ассоциативные отсылки, и поэтому становится смыслообразующим в 
процессе маркемно-семантического анализа. Так, образ сиделки «стоит на входе» пространства предчувствия разных состояний и событий:

- выздоровления Ганина (и физического, и символического);

- первой любви (пушкинское «душа ждала кого-нибудь» реализуется через указание на подобное ощущение героя: В этой комнате, где в шестнадияать лет назад выздоравливал Ганин, и зародилось то счастье, тот женский образ, который, спустя месяи, он встретил наяву [13, с. 57];

- встречи с женщиной (хотя и приятной, но все же «прохладной) и женственностью.

Представленный контекст может быть интерпретирован так: В. Набоков, со свойственной ему событийной непредсказуемостью, реализует цепь «неслучайных случайностей» в первом своем романе так: прежде чем показать богатую эмоциями жизнь, связанную с пребыванием юной девы в чувственном пространстве мужчины, он вводит в повествование старую деву. Она спасает от последствий тифа шестнадцатилетнего Ганина, помогает ему возродиться после болезни (как это потом произойдет в Берлине благодаря воспоминаниям о Машеньке), но в пространстве предчувствия уже живут и угадываются «прохладный» итог отношений героев и грусть от того, что «все пройдет».

Особенностью художественной архитектоники В. В. Набокова, о которой не раз писали исследователи, является и отказ от принципа «чеховского ружья» (т. е. следования логике «если в первом действии висит на стене ружье, то в последнем оно должно дать осечку» [15]), и вкладывание в уста глубоко несимпатичных автору героев (например, Алферова из романа «Машенька») своих сокровенных мыслей; и косвенный намек на главное настроение-ощущение, витающее над всем повествованием. В романе «Машенька» это - прохладная дымка происходящего. Так, например, романтические покровы снимаются в ключевом эпизоде интимной близости героев: $M a$ шенька вздохнула, оправила смутно белевшее платье, встала тоже. И потом, когда они или к воротам по пятнистой от луньл дорожке, Машенька подобрала с травы бледно-зеленого светляка. Она держала его на ладони, наклонив голову, и вдруг рассмеялась, сказала с чуть деревенской ужимочкой: «В обчем холодный червячок». И в это время Ганин, устальй, недовольный собой, озябший в своей легкой рубашке, думал о том, что все кончено, Машеньку он разлюбил, - и когда через несколько минут он покатил в лунную малу домой по бледной полосе шоссе, то знал, что больше к ней не приедет (выделение наше. - Ж. Г.) $[13$, с. 86]. В этом «холодном», «лунном», «зыбком», «мглистом» контексте, где СВЕТлячок (отсылка к маркеме $c в е т)$ превращается в холодного червячка, семантическая доминанта неназванной маркемы прохлада становится очевидной.

Итак, через номинацию «прохлада» автор косвенно указывает на главное настроение, витающее над всем повествованием. В романе «Машенька» это ощущение приятной, охлаждающей в летний зной атмосферы, в которую погружено пространство и время происходящего (Россия периода счастья).

Вторая узловая точка-маркема - снег. Эта маркема кодирует для В. В. Набокова понятие «Россия» во всем творчестве. Так, в стихотворении «Football» его лирический герой обозначает себя как человека «родом из дикой той страны, где каплет кровь на снег» [15], в «Машеньке» Подтягин в эмиграции «ложечкой доставая не растаявший кусочек сахара» [13, с. 72], думает «о том, что в этом ноздреватом кусочке есть что-то русское, весеннее, когда вот снег тает» [Там же]. Россия просвечивается сквозь разного рода случайные-неслучайные явления; одно из них - снег. Другая устойчивая ассоциация со словом снег в романе «Машенька» - зима как конец любви: И только в ноябре Машенька переселилась в Петербург. Они встретились под той аркой, где - в опере Чайковского-гибнет Лиза. Валил отвесно крупный мягкий снег в сером, как матовое стекло, воздухе. И Машенька в это первое петербургское свидание показалась слегка чужой, оттого, быть может, что была в иляпе и в шубке. С этого дня началась новая - снеговая эпоха их любви. Встречаться было трудно, подолгу блуждать на морозе было мучительно, искать теплой уединенности в музеях и в кинематографах было мучительнее всего, - и недаром в тех частых, пронзительно нежных письмах, которые они в пустые дни писали друг другу (он жил на Английской набережной, она на Караванной), оба вспоминали о тропинках парка, о запахе листопада, как о чем-то немыслимо дорогом и уже невозвратимом: быть может только бередили любовь свою, а может быть действительно понимали, что настоящее счастье минуло» (Выделения наши. - Ж. Г.) [13, с. 83].

\section{Заключение}

Таким образом, квантитативный маркемный анализ, произведенный на материале романа В. В. Набокова «Машенька», позволил выявить аттрактивность маркем, визуализировать ее с помощью графа, на основе которого можно сделать вывод о существовании в романе двух смысловых центров: прохлада и снег, кодирующих противопоставленные по разным линиям хронотопы романного многомирия «Машеньки»: пространство-время зарождения и расцвета любви (Воскресенск), пространство-время разрушения любви (Петербург), пространство-время рекреации (воссоздания) утраченной любви и России (взгляд на Россию из эмиграции). 
В работе представлен лишь начальный этап анализа маркем с точки зрения аттрактивно-контекстуального метода. Раздумья над графом, визуализирующим «острия слов», на которых, согласно образу А. Блока, держится «покрывало» текста, способны еще немало рассказать о тайных смыслах романа, поскольку «эти слова светятся, как звезды» (А. Блок). Но это станет предметом других статей.

\section{ЛИТЕРАТУРА}

1. Кретов А. А. Понятие маркемы : методика выявления и практика использования // Универсалии русской литературы. 2 : сб. ст. / под ред. А. А. Фаустова. Воронеж : НАУКА-ЮНИПРЕСС, 2010. С. 138-153.

2. Кретов A. A. Роль средней длины словоформы в маркемном анализе // Универсалии русской литературы. 3 : сб. ст. / под ред. А. А. Фаустова. Воронеж : Научная книга, 2011. С. 16-27.

3. Кретов А. А., Грачёва Ж. В. Традиции и инновации маркемологии в исследовании языка русских романов В. В. Набокова // Вестник Воронеж. гос. ун-та. Сер.: Лингвистика и межкультурная коммуникация. 2020. № 2. C. 114-126.

4. Фаустов А. А., Кретов А. А. Понятие маркемы и предварительные итоги маркемного анализа русской литературы // Вестник Воронеж. гос. ун-та. Сер.: Лингвистика и межкультурная коммуникация. 2017. № 4. C. $16-31$.

5. Фаустов А. А. Маркемный портрет А. П. Чехова // Вестник Воронеж. гос. ун-та. Сер.: Лингвистика и межкультурная коммуникация. 2010. № 1. С. 12-16.

6. Фаустов A. A. От ключевых слов к литературным универсалиям : несколько методологических соображений // Вестник Воронеж. гос. ун-та. Сер.: Лингвистика и межкультурная коммуникация. 2009. № 2. С. 7-11.

7. Кретов A. А. и др. Функциональный подход к выделению ключевых слов : методика и реализация // Вестник Воронеж. гос. ун-та. Сер.: Системный анализ и информационные технологии. 2009. № 1. С. 68-72.

8. Zipf G. K. Human Behavior and the Principle of Least Effort. Cambridge : Addison-Wesley Press, 1949. 573 p.

9. Zipf G. K. The Psycho-Biology of Language an introduction to dynamic philology. Cambridge : Mass. MIT Press, 1965. 336 p.

10. Титов B. Т. Частная квантитативная лексикология романских языков : монография. Воронеж : Изд-во Воронеж. гос. ун-та, 2004. 552 с.

11. Фаустов А. А., Катов М. В., Гостева А. В. Творчество А. П. Чехова в свете явления «текстовой аттракции» и ключевые произведения русской литературы // Универсалии русской литературы. 2 : сб. ст. / под ред. А. А. Фаустова. Воронеж : НАУКА-ЮНИПРЕСС, 2010. C. $154-179$.

12. Урысон Е. В. Предчувствие // Новый объяснительный словарь русского языка / под рук. акад. Ю. Д. Апресяна. М. : Языки славянской культуры ; Вена : Венский славистический альманах, 2004. С. 830-833.
13. Набоков В. В. Машенька // Собр. соч. : в 4 т. Т. 1. М. : Правда, 1990. С. 35-115.

14. Grishakova $M$. The models of space, time and vision in V. Nabokov's fiction // Narrative Strategies and Cultura Frames. Tartu Semiotics Library 5. Tartu, 2006. 324 p. URL: http://sites.utoronto.ca/tsq/24/besprozvany24.shtml

15. Набоков В. В. Энциклопедическое собрание сочинений : тексты, музыка, иллюстрации. М. : Адепт, 2003.

\section{REFERENCES}

1. Kretov A. A. Ponyatie markemy: metodika viyavleniya i praktika ispolzovaniya. [The notion of markeme: methods of determination and practice of use]. In Universals of the Russian literature 2. Collection of articles. Voronezh: NAUKA-UNIPRESS, 2010. Pp. 138-153.

2. Kretov A. A. Rol sredneij dliny slovoformy v markemnom analize [The role of the average length of the word form in the markeme analysis]. In Universals of Russian literature 3. Voronezh State University. Voronezh : Scientific Book, 2011. Pp. 16-27.

3. Kretov A. A., Gracheva Zh. V. Traditions and Innovations of Markemology in the Research of the Language of Russian Novels by V. V. Nabokov. Proceedings of Voronezh State University. Series: Linguistics and Intercultural Communication. 2020. No. 2. Pp. 114-126.

4. Faustov A. A., Kretov A. A. Ponyatie markemy I predvaritelnye itogi markemnogo analiza russkoij literatury [The concept of markeme and preliminary results of the markeme analysis of the Russian literature]. In Proceedings of the Voronezh State University. Series: Linguistics and Intercultural Communication. 2017. No. 4. Pp. 16-31.

5. Faustov A. A. Markemnyij portret A. P. Chehova [Markeme portrait of A. P. Chekhov]. In Proceedings of the Voronezh State University. Series: Linguistics and Intercultural Communication. 2010. No. 1. Pp. 12-16.

6. Faustov A. A. Ot kluchevyh slov k literaturnym universaliyam: neskolko metodicheskih soobrazheniij [From keywords to literary universals: several methodological considerations]. Proceedings of the Voronezh State University. Series: Linguistics and Intercultural Communication. 2009. No. 2. Pp. 7-11.

7. Kretov A. A., Voronina I. E., Popova I. V., Dudkina L. V. Funkcionalnyij podhod k vydeleniu kluchevyh slov: metodika i realizaciya. [A functional approach to the selection of keywords: methodology and implementation]. In Proceedings of the Voronezh State University. Series: System Analysis and Information Technology. 2009. No. 1. Pp. 6872.

8. Zipf G. K. Human Behavior and the Principle of Least Effort. Cambridge: Addison-Wesley Press, 1949. 573 p.

9. Zipf G. K. The Psycho-Biology of Language an introduction to dynamic philology. Cambridge: Mass. MIT Press, 1965. $336 \mathrm{p}$.

10. Titov V. T. Chastnaya kvantitativnaya leksikologiya romanskikh yazykov [Individual quantitative lexicology of the Romance languages]. Voronezh: Publishing house of the Voronezh State University, 2004. 552 p. 
11. Faustov A. A., Katov M. V., Gosteva A. V. Tvorchestvo A. P. Chehov v svete yavleniya "tekstovoij attrakcii" i kluchevye proizvedeniya russkoij literatury [Chekhov in the in the context of the phenomenon of the "text attraction" and key works of the Russian literature]. In Universals of the Russian literature 2. Voronezh: NAUKA-UNIPRESS, 2010. Pp. 154-179.

12. Urison E. V. Predchuvstviye [Presentiment]. In: New explanatory dictionary of the Russian language / by acad. Yu. D. Apresyan. Moscow; Vienna: Languages of Slavic Culture: Vienna Slavic Almanac, 2004. Pp. 830-833.

Воронежский государственный университет Грачева Ж. В., кандидат филологических наук, доиент, заведуюшая кафедрой издательского дела

E-mail:grachevi@mail.ru

Поступила в редакиию 10 июля 2020 г.

Принята к публикации 25 сентября 2020 2.

\section{Для цитирования:}

Грачёва Ж. В. Аттрактивные связи маркем в романе В. В. Набокова «Машенька» и их визуализация // Вестник Воронежского государственного университета. Серия: Лингвистика и межкультурная коммуникация. 2020. № 4. C. $128-138$. DOI: https://doi.org/10.17308/ lic. $2020.4 / 3088$
13. Nabokov V. V. Mashenka [Mashenka]. In Collection of essays: in 4 vol. Vol. 1. Moscow : Pravda, 1990. Pp. 35-115.

14. Grishakova M. The models of space, time and vision in V. Nabokov's fiction. In Narrative Strategies and Cultura Frames. Tartu Semiotics Library 5. Tartu, 2006. 324 p. Available at: http://sites.utoronto.ca/tsq/24/besprozvany24. shtml

15. Nabokov V. V. Enciklopedicheskoye sobraniye sochineniy: tekcti, muzika, illustraciyi [Encyclopedic Collection of Essays]: Texts, Music, Illustrations. Moscow: Adept, 2003.

Voronezh State University

Gracheva Zh. V., Candidate of Philology, Associate Professor, Head of the Publishing Depatment

E-mail:grachevi@mail.ru

Received: 10 July 2020

Accepted: 25 September 2020

\section{For citation:}

Gracheva Zh. V. Attractive connections of markemes in V. V. Nabokov's novel "Mashenka" and their visualization. Proceedings of Voronezh State University. Series: Linguistics and Intercultural Communication. 2020. No. 4. Pp. 128-138. DOI: https://doi.org/10.17308/lic.2020.4/3088 